\title{
Cytomegalovirus in biliary atresia: coincidental or causal?
}

\author{
*Devdeep Mukherjee ${ }^{1}$, Ritabrata Kundu ${ }^{1}$, Prabal Niyogi ${ }^{1}$, Joydeep Das ${ }^{1}$
}

Sri Lanka Journal of Child Health, 2016; 45(4): 256-258

DOI: http://dx.doi.org/10.4038/sljch.v45i4.8057

(Keywords- Neonatal cholestasis, extra hepatic biliary atresia, cytomegalovirus)

\section{Introduction}

Neonatal cholestasis (NC) has been documented in $19-33 \%$ of neonates with chronic liver disease attending tertiary care hospitals in India ${ }^{1-3}$. Of these, almost one third have been attributed to biliary atresia $^{3}$. Cytomegalovirus (CMV) is known to cause intrahepatic bile duct paucity and destruction and has been suggested to cause extra hepatic biliary atresia (EHBA) in a few case series ${ }^{4}$. We present a series of 4 cases admitted to our hospital over the last 18 months having EHBA with CMV infection.

Case 1: A 3 month old female baby was admitted with yellowish discolouration of eyes and urine since 3 weeks of age. She was having pale stools since 1 month of age. Investigations were suggestive of NC (table 1).

Table 1: Investigations in the 4 cases

\begin{tabular}{|c|c|c|c|c|}
\hline Investigation & Case 1 & Case 2 & Case 3 & Case 4 \\
\hline Total bilirubin & $8.4 \mathrm{mg} / \mathrm{dl}$ & $7.3 \mathrm{mg} / \mathrm{dl}$ & $12.2 \mathrm{mg} / \mathrm{dl}$ & $13.4 \mathrm{mg} / \mathrm{dl}$ \\
\hline Conjugated bilirubin & $7.0 \mathrm{mg} / \mathrm{dl}$ & $4.4 \mathrm{mg} / \mathrm{dl}$ & $7.4 \mathrm{mg} / \mathrm{dl}$ & $9.8 \mathrm{mg} / \mathrm{dl}$ \\
\hline Aspartate aminotransferase & $150 \mathrm{IU} / \mathrm{L}$ & $108 \mathrm{IU} / \mathrm{L}$ & $186 \mathrm{IU} / \mathrm{L}$ & $156 \mathrm{IU} / \mathrm{L}$ \\
\hline Alanine aminotransferase & $156 \mathrm{IU} / \mathrm{L}$ & $121 \mathrm{IU} / \mathrm{L}$ & $194 \mathrm{IU} / \mathrm{L}$ & $174 \mathrm{IU} / \mathrm{L}$ \\
\hline Gamma glutamyl transpeptidase & $1099 \mathrm{IU} / \mathrm{L}$ & $970 \mathrm{IU} / \mathrm{L}$ & $1170 \mathrm{IU} / \mathrm{L}$ & $1236 \mathrm{IU} / \mathrm{L}$ \\
\hline Alkaline phosphatase & $896 \mathrm{IU} / \mathrm{L}$ & $786 \mathrm{IU} / \mathrm{L}$ & $982 \mathrm{IU} / \mathrm{L}$ & $1049 \mathrm{IU} / \mathrm{L}$ \\
\hline International normalised ratio & 1.7 & 1.5 & 2.8 & 2.1 \\
\hline Albumin & $3.3 \mathrm{~g} / \mathrm{dl}$ & $3.2 \mathrm{~g} / \mathrm{dl}$ & $2.6 \mathrm{~g} / \mathrm{dl}$ & $2.7 \mathrm{~g} / \mathrm{dl}$ \\
\hline Alpha 1 antitrypsin & Negative & Negative & Negative & Negative \\
\hline Galactosaemia & Negative & Negative & Negative & Negative \\
\hline Ultrasonography of abdomen & $\begin{array}{c}\text { Hepatosplenomegaly } \\
\text { with ascites }\end{array}$ & Hepatosplenomegaly & Hepatosplenomegaly & $\begin{array}{c}\text { Hepatosplenomegaly } \\
\text { with ascites }\end{array}$ \\
\hline Liver biopsy & Biliary atresia & Biliary atresia & Cirrhosis & Biliary atresia \\
\hline CMV IgM $(<0.9)$ & 2.96 & 1.71 & 2.10 & 2.87 \\
\hline CMV IgG $(<6)$ & 33 & 25 & 28 & 36 \\
\hline CMV DNA PCR copies/ml & 11,626 & 7,250 & 13,328 & 18,258 \\
\hline
\end{tabular}

CMV: cytomegalovirus, IgM: immunoglobulin $M, \operatorname{Ig} G$ : immunoglobulin $G$, DNA: deoxyribonucleic acid, PCR: polymerase chain reaction

As she had CMV immunoglobulin $\mathrm{M}(\mathrm{IgM})$ and immunoglobulin $\mathrm{G}(\mathrm{IgG})$ reactive (table 1$)$, a CMV deoxyribonucleic acid (DNA) polymerase chain reaction (PCR) was sent to assess the viral load. Liver biopsy was suggestive of EHBA. Gancyclovir was started because of the high viral load and child being symptomatic. As even after 3 weeks the jaundice was persisting, Kasai portoenterostomy was done. The child continues to have conjugated hyperbilirubinemia with progressive enlargement of liver and spleen at 21 months of age.

Case 2: A 6 week old male infant was admitted with yellowish discolouration of eyes and urine and

${ }^{1}$ Department of Pediatric Medicine, Institute of Child Health, Kolkata, West Bengal, India

*Correspondence: devdeep_dm@rediffmail.com

(Received on 13 December 2015: Accepted after revision on 21 January 2016)

The authors declare that there are no conflicts of interest Personal funding was used for the project.

Open Access Article published under the Creative Commons (cC) $(7)$ occasional whitish stools since 3 weeks. On examination, he had hepatosplenomegaly. CMV DNA PCR was suggestive of infection and liver biopsy of EHBA (Table 1). Liver transplant was advised but not done due to financial constraints. Kasai portoenterostomy was done within 2 weeks of diagnosis. At 8 months, child has conjugated jaundice with deranged liver enzymes and firm and enlarged liver and spleen.

Case 3: A 7 month old girl was admitted with jaundice since 1 month of age and clay coloured stools. She had a distended abdomen, ascites and hepatosplenomegaly. Hepatic technetium-99mmebrofennin iminodiacetate (HIDA) scan was suggestive of biliary atresia. Liver biopsy showed cirrhotic changes. CMV DNA PCR was significantly elevated (table 1). She was given supportive management and died after 1 month.

Case 4: A 5 month old girl presented with jaundice and clay coloured stools since 2 weeks of age. She had hepatosplenomegaly. Liver biopsy was suggestive of EHBA and CMV DNA PCR was significantly elevated (Table 1). Gancyclovir was 
administered for 2 weeks. Her jaundice persisted and she was lost to follow up.

All 4 cases were diagnosed as having EHBA with concomitant CMV infection. None had hearing or vision abnormalities. Head circumference was normal for age in all 4 babies.

\section{Discussion}

Viral infection has been proposed as a cause of EHBA. In a study from Pakistan, patients with EHBA were searched for evidence of infection with CMV, Epstein Barr virus, toxoplasma, herpes, hepatitis B and $\mathrm{C}$. It was concluded that CMV may play a role in pathogenesis of $\mathrm{EHBA}^{5}$. In a study from Brazil on 76 patients with NC, CMV IgM was positive in $28.5 \%$ patients with extra hepatic cholestasis and $29.4 \%$ with intra hepatic cholestasis $^{6}$. All our 4 patients had CMV IgM positive along with significantly detectable copies of CMV DNA PCR. The liver enzymes, HIDA and liver biopsy were suggestive of EHBA.

Cases 1 and 2 underwent Kasai portoenterostomy without any improvement in follow up. Case 1 underwent the operation after 3 months and case 2 underwent it early. A study from London found CMV IgM positive cases with biliary atresia as a distinct entity with late presentation and a poor response to Kasai operation. Except case 2 who presented early, all other patients presented late. Two patients underwent operation with poor response in follow up. Cases 1, 3 and 4 also had significant inflammation and fibrotic changes on liver biopsy as has been documented in this study ${ }^{7}$. A study from China reports a strong association between CMV and lower rate of jaundice disappearance following operation. They also found increased fibrosis as we found in our patients ${ }^{8}$. However a study from Canada, with CMV DNA analysis on bile duct biopsy specimens showed negative results ruling out any association of CMV involved in the pathogenesis of EHBA ${ }^{9}$.

There is still no consensus on whether the association between CMV and EHBA is causal or coincidental. A study by Tarr et al has stated that infants with cholestasis with CMV infection should also be investigated for EHBA and monitored accordingly ${ }^{10}$. Till further data are available, CMV should be considered as a potential aetiological agent for EHBA with poor prognosis even after operative intervention.

\section{References}

1. Consensus report on neonatal cholestasis syndrome. Pediatric Gastroenterology Subspecialty Chapter of Indian Academy of Pediatrics. Indian Pediatrics 2000; 37:845-51.

PMid: 10951633

2. Yachha SK, Sharma BC, Khanduri A, Srivastava A. Current spectrum of hepatobiliary disorders in northern India. Indian Pediatrics 1997; 34:885-90. PMid: 9567550

3. Bhatia V, Bavdekar A, Matthai J, Waikar Y, Sibal A. Management of neonatal cholestasis: consensus statement of the Pediatric Gastroenterology Chapter of Indian Academy of Pediatrics; Indian Pediatrics 2014; 51(3):203-10. http://dx.doi.org/10.1007/s13312-0140375-2

PMid: 24736908

4. Mohanty S, Shah I, Bhatnagar S. Evolving biliary atresia with cytomegalovirus; Indian Pediatrics 2011; 48: 644-6.

PMid: 21918271

5. Soomro GB, Abbas Z, Hassan M, Luck $\mathrm{N}$, Memon Y, Khan AW. Is there any association of extra hepatic biliary atresia with cytomegalovirus or other infections? Journal of the Pakistan Medical Association 2011; 61(3):281-3.

PMid: 21465946

6. Oliveira NL, Kanawaty FR, Costa $\mathrm{SC}$, Hessel G; Infection by cytomegalovirus in patients with neonatal cholestasis; Arq Gastroenterol. 2002; 39(2):132-6. http://dx.doi.org/10.1590/S000428032002 000200012

PMid: 12612719

7. Zani A, Quaglia A, Hadzić N, Zuckerman M, Davenport M; Cytomegalovirusassociated biliary atresia: An aetiological and prognostic subgroup. Journal of Pediatric Surgery 2015; 50(10):1739-45. http://dx.doi.org/10.1016/j.jpedsurg.2015. 03.001

PMid: 25824438

8. Shen C, Zheng S, Wang W, Xiao XM. Relationship between prognosis of biliary atresia and infection of cytomegalovirus; World Journal of Pediatrics 2008; 4(2): 123-6. http://dx.doi.org/10.1007/s12519-0080024-8

PMid: 18661768 
9. Jevon GP, Dimmick JE. Biliary atresia and cytomegalovirus infection: a DNA study. Pediatric and Developmental Pathology 1999; 2(1):11-4. http://dx.doi.org/10.1007/s100249900083
10. Tarr PI, Haas JE, Christie DL. Biliary atresia, cytomegalovirus, and age at referral; Pediatrics 1996; 97(6): 828-31

PMid: 8657522 